\title{
Plant diversity in the indigenous home gardens in the Eastern Himalayan region of Mizoram, Northeast India.
}

\author{
A.R. Barbhuiya ${ }^{a *}$, U.K. Sahoo ${ }^{\mathrm{b}}$ and K. Upadhyaya ${ }^{\mathrm{b}}$ \\ aBiology Department, Concordia University, 7141 Sherbrooke Street West, Montreal, Quebec \\ H4B 1R6, Canada. \\ bepartment of Forestry, Mizoram University, Tanhril, P.O. Box \# 190, Aizawl, Mizoram, India. \\ (*Corresponding author email: arbarbhuiya@gmail.com)
}

\begin{abstract}
The eastern Himalayan region of Northeast India is well known for its traditional home gardens, which are considered to play important roles in the maintenance of livelihoods of indigenous communities and conservation of biological diversity. This study determines the plant diversity in home gardens and their importance in conservation of PGR through utilization. We studied 90 home gardens in details located in 6 villages in two different locations. Different aspect about the home gardens and plant species were observed directly and thorough discussion with the farmers. A total of 333 plant species (133 trees, 92 shrubs and 108 herbs) belonging to 128 families with an average of 78 species per home garden were recorded. The size of home gardens ranged between $0.10-0.60$ ha and showed significant $(\mathrm{P}<0.001)$ positive correlation between the garden size and plant species diversity. The species diversity index for trees, shrubs and herbs was $4.76,4.39$ and 4.58 respectively. The species similarity within each life-form was high with $50 \%$ for trees, $38 \%$ for shrubs and $49 \%$ for herbs. Plant species in the home gardens could be grouped into 11 major use categories and majority of plants were of medicinal or multiple use categories. These home gardens are reservoirs of PGR and play a vital role in sustaining the livelihood of local inhabitants. They are also functioning as a domestication and conservation centers of many crop relatives.
\end{abstract}

Key words: Diversity, Homegarden, Indigenous, Northeast India, Plant, People, Tribe. 


\section{Introduction}

Home gardens are considered as one of the oldest subsistence farming systems practiced by rural communities in many parts of the world, and can include multi-layer systems of trees, shrubs and herbs around homesteads (Kumar and Nair 2004; Kabir and Webb 2009; Idohoua et al. 2014; Salako et al. 2014). Home gardens are generally multifunctional and play key roles in providing ecosystem services and numerous benefits for sustaining the livelihood of local inhabitants (Galluzzi et al. 2010; Calvet-Mir et al. 2012; Reyes-Garcia et al. 2012; Clarke et al. 2014). Home gardens are important as a means of maintaining PGR (plant genetic resources) (Agelet et al. 2000; Sunwar et al. 2006), as potential hotspots of agricultural biodiversity (Kumar and Nair 2004; Galluzzi et al. 2010; Taylor and Lovell 2014), and as natural resources for alleviating poverty (Reyes-Garcia et al. 2012; Salako et al. 2014). In addition, they represent a viable solution for biodiversity conservation as ex-situ and in-situ conservation areas for rare and threatened species (Kabir and Webb 2009; Roy et al. 2013).

The home gardens in the eastern Himalayan region of Northeast India (NEI) are known to have played an important role in the domestication of many plants and crop varieties. Home gardening in NEI is believed to have evolved with the local practice of jhum agriculture, the slashing and burning of the forest; that results in the loss of topsoil and nutrients, leading to habitat degradation. Farmers of the region have recognized the adverse impacts of jhum agriculture and consequently developed a preference for home gardening over jhum for the maintenance of crop diversity, household food security, nutrition and subsistence income. Such systems in NEI resemble the agroforestry systems practiced in many parts of the world, and serve as an important source of various resources for local inhabitants. The objectives of this study were to gain insights into plant diversity and their importance in conservation of PGR. The 
specific questions addressed are, 1) What is the plant species composition in home gardens? 2) Is there a correlation between home garden size and plant species diversity? and 3) What are the uses of plants in home gardens and their relevance in conservation of PGR?

\section{Methods}

\section{Study site}

This study was conducted in six villages located in Aizawl and Serchhip districts in Mizoram, NEI. Mizoram or 'land of the hill people' is located within the Indo-Burma biodiversity hotspot at the far end of the Himalayan mountain range having ca. $91 \%$ area under forest cover. It lies between $92^{\circ} 15^{\prime}$ and $93^{\circ} 26^{\prime} \mathrm{E}$ longitude and $21^{\circ} 58^{\prime}$ and $24^{\circ} 35^{\prime} \mathrm{N}$ latitude, with an altitudinal range of $21-2157 \mathrm{~m} \mathrm{msl}$. The climate of the area is moist tropical to sub-tropical and the temperature ranges between $20^{\circ}-30^{\circ} \mathrm{C}$ and $7^{\circ}-18^{\circ} \mathrm{C}$ during summer and winter and receives an annual rainfall of $2000-3200 \mathrm{~mm}$. The topography of the study sites is highly undulated, and most agricultural practices are performed in the upland areas. We studied 90 indigenous home gardens located in six selected villages in Mizoram. Three villages (Selesih, Sairang and Thingsulthliah) in Aizawl, while the other three villages (Serchhip, Keitum and Chaitlang) in Serchhip (Figure 1). Data describing the extent and elevation of the areas encompassing the home gardens in each village are given in Table 1.

\section{Data collection and analysis}

We requested voluntary participation from home garden owners and field surveys were conducted during March to October 2008. After a preliminary survey of 35 home gardens (ca. $23 \%$ of the home gardens in each village), 15 gardens in each village (a total of 90 home gardens) were chosen for detailed study. Garden owners provided information of the social customs surrounding gardening practices. Information on plant species composition and uses of 
each species was collected through direct observation and discussion with the farmers. We measured the area of total plant cover in each garden after excluding the dwelling area. Data collection was conducted in each home garden during the peak sowing and growing (April-June) and harvesting (June-September) seasons of the year. In each garden, species composition was enumerated by randomly placing five $10 \mathrm{~m}$ x $10 \mathrm{~m}$ quadrats for trees. Within each of these quadrats, another $5 \mathrm{~m} \times 5 \mathrm{~m}$ quadrat for shrubs and a $1 \mathrm{~m} \times 1 \mathrm{~m}$ quadrat for herbs were established. Species richness was calculated as the number of species encountered in all quadrats grouped by habit forms. The local names of all plants were recorded, and each was identified to species level in consultation with the herbarium at the Mizoram University and taxonomists at regional herbaria of the Botanical Survey of India, Shillong. Plants with multiple uses were classified by main use, into categories including fencing, food, fuel-wood, fruits, medicinal, ornamental, roofs, timber, trade and spice. Plant species with several uses other than the above mentioned categories were included in the "other" category, which includes a variety of uses including shade, timber, fiber, and soil fertility.

The plants in each quadrat were counted, and a t-test was performed to identify the significant differences in the mean values of species richness. The diversity and abundance of plants in home gardens between villages were examined using ANOVA (SPSS 16.0) at two scales, garden and village. Garden level plant diversity and abundance were compared within the home garden in each village and overall among six villages. The data collected in the quadrats were used to determine the frequency, density and dominance, following Phillips (1959). Species diversity was calculated using the Shannon-Weaver index of diversity: $\mathrm{H}^{\prime}=-\sum\left\{\left(n_{i} / N\right) \ln \left(n_{i} /\right.\right.$ $N)$ \}, where $n_{i}=$ importance value index (IVI) of a species, $N=$ total IVI of the community. The IVI was calculated following Salako et al. (2014) to analyze the importance of each species in 
each home garden and in each village. The dominance index (Simpson 1949) of the community was calculated as: $\mathrm{C}=\sum\left\{\left(\mathrm{n}_{\mathrm{i}} / \mathrm{N}\right)^{2}\right\}$, where $\mathrm{n}_{\mathrm{i}}$ and $\mathrm{N}$ are same as for Shannon's index. Pielou's (1966) evenness index was calculated as: $\mathrm{e}=\mathrm{H}^{\prime} / \log (\mathrm{S})$, where $\mathrm{H}^{\prime}=$ the Shannon-Weaver index of diversity, and S = total number of species. Sorensen's similarity index (Sorensen 1948) was calculated as, $[2 \mathrm{C} /(\mathrm{A}+\mathrm{B})] \times 100]$, where $\mathrm{A}$ and $\mathrm{B}$ are the total species content in stand $\mathrm{A}$ and $\mathrm{B}$ respectively, while $\mathrm{C}$ is the number of species common to both stands.

\section{Results}

The physical location and sociological characteristics of the study villages are given in Table 1. The average number of households in six villages was 663 with the highest number of households (1051) in Sairang and the lowest (308) in Chhiahtlang. Among the 3981 hou seholds in six villages, only 441 households (11\%) had home gardens (Table 1). These home gardens are mostly rainwater fed, and water harvesting technology in the villages is almost non-existent due to steep slopes coupled with poor water-holding capacity of the soil. Almost all gardeners use traditional tools such as khurpi, shovel, spade, sickle, knife and other traditional practices of manual weeding and pest control. Soil fertility of the home gardens is maintained through natural means using organic manures produced at home through composting leftover crops. In general, all adult family members contribute equal labor to the overall maintenance and management of gardens; men select cash crops, trees and fruit species and obtain and sow seed materials, while women mainly grow and manage vegetables, spices, medicinal plants, and harvest and market superfluous crops.

A wide variation in home garden sizes was observed and the area ranged between 1421$6027 \mathrm{~m}^{2} \pm$ S.E. 330 in Sairang, $1047-5462 \mathrm{~m}^{2} \pm$ S.E. 295 in Selesih, $1064-4321 \mathrm{~m}^{2} \pm$ S.E. 223 in Thingsulthliah, $1127-4867 \mathrm{~m}^{2} \pm$ S.E. 240 in Serchhip, $1245-3891 \mathrm{~m}^{2} \pm$ S.E. 207 in Keitum 
and $1098-3245 \mathrm{~m}^{2} \pm$ S.E. 179 in Chhitahlang. In general, home gardens located in Serchhip are relatively smaller $(\mathrm{P}<0.001 ; \mathrm{t}(44)=5.085)$ then the home gardens in Aizawl (Table 1$)$.

\section{Species richness and diversity}

A total of 128 plant families were recorded in the present study (Table S1). The most common plant families (Figure 2) were Fabacece, Rutaceae, Zingiberaceae, Solanaceae, Euphorbiaceae, Asteraceae and Cucurbitaceae, which contained 25, 18, 14, 13, 11 and 10 species respectively. The highest numbers of food plants were from the family Fabaceae and the family Rutaceae contributed maximum number of fruits and medicinal plants. The most abundant tree species included Areca cathechu, Artocarpus heterophyllus, Mangifera indica, Parkia timoriana and several Citrus species. The most dominant shrubs species were Amaranthus viridis, Cajanus cajan, Calamus erectus, Capsicum annum, Carica papaya, Clerodendrum colebrookianum, Hibiscus macrophyllus, Murraya koenigii and large number of Musa and Solanum species. The dominant herbaceous species were Ageratum conyzoides a few number of Allium, Brassica, Cucurbita species etc (Table S1).

The number of plant species in each home garden ranged from 36 to 167, with an average of 78 species in each garden suggesting a high inter-garden variation in overall species composition and richness. The species accumulation curve based on 90 gardens sampled in the area did not reach an asymptote, indicating that home gardens in the region may contain more species diversity. The lack of an asymptote further indicates that multiple species share dominance in the overall structural community of the home gardens (Figure 3). Majority (85\%) of the species were represented in a broad range of frequency $(5-40 \%)$ classes and only a few $(15 \%)$ in high frequency classes $(41-75 \%)$ (Figure 4) indicating occurrence of large number of species in those gardens. A total of 333 plant species were found and trees were the most 
abundant (133 species, 40\%), followed by 108 (32\%) of herbs and 92 (28\%) shrubs. Overall, 96 genera of trees in 52 families, 59 genera of shrubs in 36 families and 59 genera of herbaceous plants belonging to 52 families (Table 2). Species richness varied significantly [Mean=1124.55, $\mathrm{SD}=1292.65 ; \mathrm{t}(44)=5.83, \mathrm{P}=0.001]$ among villages with highest number of species in Sairang followed by Serchhip and the lowest in Thingsulthliah (Table 2).

Species diversity indices for trees, shrubs and herbs varied significantly [Mean=4.11, $\mathrm{SD}=0.288 ; \mathrm{t}(17)=60.41, \mathrm{P}=0.001]$ within gardens. Overall, the tree species diversity was higher $(\mathrm{F}=6.84, \mathrm{P}=0.01$; ANOVA) than the herb and shrub. Evenness index for trees, shrubs and herbs also showed a trend similar to the diversity index values and varied slightly within gardens $(\mathrm{P}<0.05)$. The evenness values were higher in the small gardens in Selesih and lower in the large gardens in Sairang (Table 2). The similarity indices of trees, shrubs and herbs were high (91\%) between gardens in Selesih and Sairang followed by Thingsulthliah and Sairang (88\%). The lowest similarity values (68\%) were observed among the gardens of Serchhip and Selesih. The tree species similarity indices showed significant variation $[$ Mean=70.76, $\mathrm{SD}=6.33 ; \mathrm{t}(14)=43.23$, $\mathrm{P}=0.001$ ] among gardens with highest similarity (87\%) between gardens in Selesih and Sairang and the lowest in Keitum and Chhiahtlang (51\%) (Table 3). In general, 66 trees (50\%), 35 shrubs (38\%) and 53 herb (49\%) species were common to all gardens.

\section{Stratification and functional diversity}

All home gardens were composed of a mixture of herb, shrub and tree species forming multiple layers of different species with three to four distinct vertical stratifications. The uppermost canopy consisted of trees and therefore a perennial layer. Annual and perennial plants are found immediately below this layer. The third storey consisted of a variety of perennial shrub species 
of medicinal and crop plants. The lowest ground storey consisted of species that are $20 \mathrm{~cm}$ or less in height and are varieties of widely used vegetables crops.

Based on uses, the overall plant species were broadly categorized into eleven groups. The species under different use category were well represented in each surveyed garden. Medicinally important plants had the major (33\%) constituents followed by food (16\%), fruits (10\%), ornamental (6\%), timber (5\%) and fuel wood (2\%), trade and spice (2\%) and $1 \%$ each of roofing and fencing category, with a large proportion of plants $(22 \%)$ having multiple uses. Different tree species have been found to be associated with various socio-economic and ecological roles. As an example, a large number of timber species (5\%) are used for the construction of houses and furniture and many other multiple functions. Several species were planted as living fences between gardens and to protect crops from wild animals. A few evergreen and perennial tree species also have a number of ecological importances besides their timber and fuel wood supply. The ecological services includes shade for the under canopy trees and improved soil fertility through leaf litter decomposition. According to farmer many annual crops shows better yield when they are in association with a few nitrogen fixing plants. A number of plant species found to be common in almost all of the home gardens because of its wide economic and ecological roles in these systems; good economic return through sale. In general, these home gardens are the potential source of different bio-products for the overall and basic need of the practicing families of the hill region.

\section{Discussion}

The mountainous region of Mizoram in the Indo-Burma biodiversity hot spot is home to many indigenous communities with unique life styles who are accustomed to live in steep slopes using locally available natural resources. Increased population and urbanization in many parts of India 
lead to reduction in forest cover. However, the mountain areas of Mizoram have not experienced extensive deforestation except for shifting cultivation. These home gardens are the primary agricultural land and the source of year round supply of food and other daily necessities. The ownership of these gardens passed from one generation to the next and maintained as permanent family gardens, sustaining productivity for many generations without major changes in the composition of plant communities. In addition, maintenance of large number of species in home gardens provides indirect benefits and ecological services. Similar services from home gardens throughout the world has been reported (Fernandes and Nair 1986; Mendez et al. 2001; Sunwar et al. 2006; Calvet-Mir et al. 2012; Clarke et al. 2014; Idohoua et al. 2014).

The size of home gardens in Mizoram ranged between $0.10-0.60$ ha, which is similar to global average home garden sizes of $0.10-0.50$ ha (Fernandes and Nair 1986; Kumar et al. 1994; Das and Das 2005). The plant diversity and home garden productivity is largely a function of the garden size and large home gardens provide sufficient products for the own consumption as well as significant financial gains through sale of extra products. Our study has shown significant positive correlation $(\mathrm{R}=0.820, \mathrm{P}<0.001)$ between the size and total species diversity (Table 4). The farmers constrained with land shortage concentrate on fewer species with high usage and allocate more land area for food crops as evident by the significant $(\mathrm{R}=0.650$, $\mathrm{P}<0.001$ ) positive correlation between garden size and plants used for food (Table 4). This pattern of increasing tree species richness with increasing land holding also reported in other home gardens (Kumar et al. 1994; Mendez et al. 2001; Zhang and Jim 2014).

Representation of over three hundred species in diverse plant families and genera with an average of 78 species per garden highlights their species richness (Table 2). In general plant richness estimated is relatively higher than the other reported home gardens of India including 
Assam in NEI (Das and Das 2005), Karnataka (Shastri et al. 2002) and Kerala (Kumar et al. 1994). Several home garden surveys in the other areas of the world, 278 species in China (Clarke et al. 2014), 281 in Mexico (Larios et al. 2013), 200 species in Thailand (Makaraphirom 1989) and 62 species in Bangladesh (Roy et al. 2013). High species richness and diverse plant composition provide a wide range of choices of plant material to meet diverse farmer needs. The species diversity index for tree, shrub and herb in the present study was 4.76, 4.39 and 4.58 respectively (Table 2). The species diversity index values are higher than the corresponding values of home gardens in various parts of the world: $0.50-3.30$ in Hong Kong (Zhang and Jim 2014), $1.007-3.153$ in Tehuaccn Valley, Mexico (Larios et al. 2013), $1.9-2.7$ in Thailand (Gajaseni and Gajaseni 1999), 2.30 - 3.39 in Bangladesh (Roy et al. 2013), 2.43-3.84 in up and low lands areas of Mexico (Gliessman 1990a), 3.21 in Karnataka, India (Shastri et al. 2002), 3.55 in Costa Rica (Gliessman 1990b). The species diversity index of home gardens in Mizoram are similar to the values $(4.03-4.42)$ reported from home gardens in western Nepal (Sunwar et al. 2006). The high diversity values found in those gardens highlights their richness and are related to several factors such as varied geography, favorable microclimates, long history, introduction of species from the nearby forest, exchange and sharing of resources by the communities. Multiple nutritional demands and year round needs of various products also increased the diversity in those home gardens. Dominance index values ranged between $0.164-0.373$ and overall low dominance indices explain the heterogeneity and richness in species composition with greater dominance of trees followed by herbs and shrubs (Table 2). The greater evenness values of $0.970-0.978$ indicate that greater percentage of the species is uniformly distributed in different gardens. In general, high evenness and low dominance values in the gardens confirm that those gardens are not occupied by limited number of species, however, abundant number of 
species. Greater species similarities are due to the reason that tribal communities in all the villages are from same ethnic group and their common management and conservation strategies. Some variation arises may be due to individual family species preference, size of garden, altitude and soil fertility status.

In regard to vertical structure, different species composition and perennial habits of large number of plants make these gardens resemble to tropical forests. Vertical stratification in vegetation makes such system more productive by capturing light sources and uptake of soil nutrients by different root systems. On the other hand, many shade loving crop plants receive optimum environment for their growth and yield. Different climbing crops receive physical support from other plants and act as host for a number of epiphytes. The indigenous tribal communities of the region have developed and learned similar management strategies through generations. Furthermore, similar practices may have evolved through direct observations and cultural experiences.

The presence of crops with different functions and habits fulfills the nutritional and financial needs of the farmer. Home garden plants are used for food and fruit production as well as medicinal products. These results are also consistent with findings from other studies that highlighted the importance of home gardens in producing healthy food and economic support to the gardener (Calvet-Mir et al. 2012; Reyes-Garcia et al. 2012). The perennial nature of these garden and combination of herbaceous vegetables, shrubs and trees form mixed and balanced production system. This might play an important role in ecological sustainability and stability through effective management strategies by the owner of these gardens. Dietary changes have resulted in increased diversity of cultivated vegetable species, including exotic and improved varieties in combination with the landraces.Thus, traditional knowledge associated with the 
cultivation of indigenous wild crops are maintained along with domesticated and improved varieties of crops.

The high intra-specific diversity observed in many species of different plant families viz., Araceae (6), Musaceae (8), Polygonaceae (5), Rutaceae (14), Solanaceae (10) and Zingiberaceae (8) could be attributable to the introduction of crop plants from wild sources, preference of the farmer and selection for desired traits. This also suggests that these gardens maintain wild crop relatives and could serve as an important center of plant domestication. Human regulated back yard and kitchen gardens always play important role in domestication and further utilization of wild crops through hybridization (Hughes et al. 2007). Other studies also reported maintenance of landraces and a wide range of genetic diversity to be a highly valued ecosystem service provided by home gardens (Calvet-Mir et al. 2012). Although a very limited number of species recorded from home gardens are commercialized, many of the species are endemic to the region (e.g. A. chama, A. lakoocha, C. indica, C. tamala, C. macroptera, M. champaca, O. indicum, S. khasiana, etc). As per IUCN endangered and threatened categories, the species like Bombax insignae, B. flabellifer, Centella asiatica, C. macroptera, C. rugulosa, Garcinia cowa, Hedychium spicatum, Livistona chinensis, Mangifera sylvatica and Rauvolfia serpentina, were also encountered in the different home gardens. Which suggest that home gardens also appeared to host many endangered and threatened species along with high endemic species of the region.

\section{Conclusion}

Home gardening in the hilly region of Mizoram is an important agricultural system for food, fruits, vegetables, and medicine. The diversity and incorporation of native and introduced species, and cultural practices make the home gardens in the region a sustainable agricultural system. Home gardens in the region are effective reservoirs of diverse PGR. These gardens serve 
as an important means of conservation of native plants through use and reducing pressure on wild resources. The availability of wild relatives of crops, abundant genetic diversity, and landraces provide a unique opportunity for crop improvement.

\section{Acknowledgment}

We are grateful to home garden owners of Aizawl and Serchhip districts of Mizoram for permission to work in their gardens. Thanks are due to the staff of Botanical Survey of India, Northeast Circle Shillong for help in plant identification. Thanks to the CSIR, Govt. of India, for financial support and finally ARB thanks S. Dayanandan, Biology Dept., Concordia University for discussion and comments.

\section{Literature Cited}

Agelet, A., M.A. Bonet, and J. Valles. 2000. Home gardens and their role as a main source of medicinal plants in mountain regions of Catalonia (Iberian Peninsula). Economic Botany 54: 295-309.

Calvet-Mir, L., E. Gomez-Baggethun, and V. Reyes-Garcia. 2012. Beyond food production: Ecosystem services provided by home gardens. A case study in Vall Fosca, Catalan Pyrenees, Northeastern Spain. Ecological Economics 74: 153-160.

Census of India. 2011. Registrar Publication. New Delhi: Government of India.

Clarke, L.W., L. Li, G.D. Jenerette, and Z. Yu. 2014. Drivers of plant biodiversity and ecosystem service production in home gardens across the Beijing Municipality of China. Urban Ecosystem, doi 10.1007/s11252-014-0351-6.

Das, T. and A.K. Das. 2005. Inventorying plant biodiversity in home gardens: A case study in Barak Valley, Assam, North East India. Current Science 89: 155-163. 
Fernandes, E.C.M. and P.K.R. Nair. 1986. An evaluation of the structure and function of tropical homegardens. Agriculture System 21: 279-310.

Gajaseni, J. and N. Gajaseni. 1999. Ecological rationalities of the traditional home garden system in the Chao Phraya Basin, Thailand. Agroforestry System 46: 3-23.

Galluzzi, G., P. Eyzaguirre, and V. Negri. 2010 Home gardens: neglected hotspots of agrobiodiversity and cultural diversity. Biodiversity Conservation 19: 3635-3654.

Gliessman, S.R. 1990a. Integrating trees into agriculture: the home garden agro-ecosystem as an example of agro-forestry in the tropics. in S.R. Gliessman, eds., Agroecology: Researching the Ecological Basis for Sustainable Agriculture, Springer-Verlag, New York, pp.160-168.

Gliessman, S.R. 1990b. Understanding the basis for sustainability for agriculture in the tropics: experiences in Latin America. in C.A. Edwards, R. Lal, P. Madden, R.H. Miller, and G. House, eds., Sustainable Agricultural Systems, St. Lucie Press, Delray Beach, Florida, pp. 378-390.

Hughes, C.E., R. Govindarajulu, A. Robertson, D.L. Filer, S.A. Harris, and C.D. Bailey. 2007. Serendipitous backyard hybridization and the origin of crops. PNAS 104: 14389-14394. Idohoua, R., B. Fandohanabc, V.K. Salakoa, B. Kassaa, R.C. Gbedomona, H. Yedomonhana, R. Lucas, G. Kakaia, and A.E. Assogbadjo. 2014 Biodiversity conservation in home gardens: traditional knowledge, use patterns and implications for management. International Journal of Biodiversity Sciences and Ecosystem Service Management 10: 89-100.

Kabir, M.E. and E.L. Webb. 2009. Hou sehold and home garden characteristics in southwestern Bangladesh. Agroforestry System 75: 129-145.

Kumar, B.M. and P.K.R. Nair. 2004. The enigma of tropical home gardens. Agroforestry System 61: 135-152. 
Kumar, B.M., S.J. George, and S. Chinnamanis. 1994. Diversity, structure and standing stock of wood in the home gardens of Kerala in Peninsular India. Agroforestry System 25: 243-262.

Larios, C., A. Casas, M. Vallejo, A.I. Moreno-Calles, and J. Blancas. 2013. Plant management and biodiversity conservation in Nahuatl homegardens of the Tehuacan Valley, Mexico. Journal of Ethnobiology and Ethnomedicine 9: 74. doi:10.1186/1746-4269-9-74

Makaraphirom, P. 1989. Checklist of Species for Extension in Agroforestry Systems. Agroforestry Research 30, Royal Forestry Department, Bangkok, Thailand.

Mendez, V.E., R. Lok, and E. Somarriba. 2001. Interdisciplinary Analysis of home gardens in Nicaragua: Micro-zonation, plant use and socioeconomic importance. Agroforestry System 51: 85-96.

Phillips, E.A. 1959. Methods of Vegetation Study. Henry Holt \& Company, New York.

Pielou, E.C. 1969. An Introduction to Mathematical Ecology. Wiley, New York.

Reyes-Garcia, V., L. Aceituno, S. Vila, L. Calvet-Mir, T. Garnatje, A. Jesch, J.J, Lastra, M. Parada, M. Rigat, J. Valles, and M. Pardo-de-Santayana. 2012. Home gardens in three mountain regions of the Iberian Peninsula: description, motivation for gardening, and gross financial benefits. Journal of Sustainable Agriculture 36: 249-270.

Roy, B., M.H. Rahman, and M.J. Fardusi. 2013. Status, diversity, and traditional uses of homestead gardens in Northern Bangladesh: A means of sustainable biodiversity conservation. ISRN Biodiversity, doi.org/10.1155/2013/124103.

Salako, V.K., B. Fandohan, B. Kassa, A.E.Assogbadjo, A.F.R. Idohou, R.C. Gbedomon, S. Chakeredza, M.E. Dulloo, and R.G. Kaka. 2014. Home gardens: an assessment of their biodiversity and potential contribution to conservation of threatened species and crop wild relatives in Benin. Genetic Resources and Crop Evolution 61: 313-330. 
Shannon, E.C. and W. Weaver. 1963. The Mathematical Theory of Communication. Urbana, IL: University of Illinois Press.

Shastri, C.M., D.M. Bhat, B.C. Nagaraja, K.S. Murali, and N.H. Ravindranath. 2002. Tree species diversity in a village ecosystem in Uttara Kannada district in Western Ghats, Karnataka. Current Science 82:1080-1084.

Simpson, E.H. 1949. Measurement of diversity. Nature 163: 688.

Sorensen, T. 1948. A method of estimating group of equal amplitude in plant society based on similarity of species content and its application to analyses of the vegetation on Danish commons. Biologiske Skrifter 5: 1-34.

Sunwar, S., C.G. Thornstrom, A.Subedi, and M. Bystrom. 2006. Homegardens in western Nepal: opportunities and challenges for on-farm management of Agro-biodiversity. Biodiversity Conservation 15: 4211-4238.

Taylor, J.R. and S.T. Lovell. 2014. Urban home gardens in the Global North: A mixed methods study of ethnic and migrant home gardens in Chicago, IL. Renewable Agriculture and Food System, doi:10.1017/S1742170514000180.

Zhang, H. and C.Y. Jim. 2014. Species diversity and performance assessment of trees in domestic gardens. Landscape and Urban Planning 128: 23-34.

\section{Supporting information}

Appendix 1. Table S1. List of plant species, density, uses and IVI in the home gardens. 
Table 1. Survey results describing physical and sociological characteristics of study sites. Population information from Census of India (2011).

\begin{tabular}{lcccccc}
\hline & \multicolumn{3}{c}{ Aizawl district } & \multicolumn{3}{c}{ Serchhip district } \\
& Sairang & Selesih & Thingsulthlia & Serchhip & Keitum & Chhiahtlang \\
\hline Population & 5034 & 4779 & 3402 & 3865 & 2022 & 4142 \\
No. of households & 1051 & 873 & 724 & 613 & 412 & 308 \\
No. of adult males & 2829 & 2409 & 1663 & 1947 & 1007 & 2137 \\
No. of adult females & 2205 & 2370 & 1739 & 1918 & 1015 & 2005 \\
Average garden size $\left(\mathrm{m}^{2}\right) 4297$ & 3887 & 2874 & 3159 & 2556 & 2211 \\
Distance from market $(\mathrm{km}) 19$ & 12 & 47 & 4 & 16 & 10 \\
\hline
\end{tabular}


Table 2. Species richness and community indices (Shannon diversity $=H^{\prime}=-\sum\left\{\left(n_{i} / N\right) \log _{e}\right.$ $\left.\left(\mathrm{n}_{\mathrm{i}} / \mathrm{N}\right)\right\}$; Dominance index $=\mathrm{C}=\sum\left\{\left(\mathrm{n}_{\mathrm{i}} / \mathrm{N}\right)^{2}\right\}$; Pielou's evenness index $\left.=\mathrm{e}=\mathrm{H}^{\prime} / \operatorname{logs}\right)$ of home gardens.

\begin{tabular}{lllll}
\hline Parameters Sairang Selesih Thingsulthliah Serchhip Keitum Chhiahtlang Overall & S
\end{tabular}

\section{Total number of species}

Trees

110

$94 \quad 93$

97

96

99

133

Shrubs

63

52

40

61

67

58

92

Herbs

88

61

35

74

55

66

108

Number of genera

Trees

Shrubs

83

Herbs

44

69

\section{Number of families}

$\begin{array}{ll}\text { Trees } & 42 \\ \text { Shrubs } & 26\end{array}$

Herbs

42

26

33

Diversity index

$\begin{array}{llll}\text { Trees } & 4.05 & 4.44 & 4.42 \\ \text { Shrubs } & 4.06 & 3.87 & 3.61 \\ \text { Herbs } & 4.40 & 4.04 & 3.48\end{array}$

\section{Dominance index}

Trees

$$
0.164
$$

0.237

0.240

0.237

4.45

4.43

4.11

4.00

4.23

3.94

0.355

0.280

0.239

0.239

0.200

Shrubs

0.287

0.316

0.373

0.264

0.296

0.305

0.246

Herbs

$$
0.241
$$

0.290

0.304

0.274

0.220

\section{Evenness index}

\begin{tabular}{llllllll} 
Trees & 0.863 & 0.978 & 0.975 & 0.972 & 0.971 & 0.966 & 0.971 \\
Shrubs & 0.980 & 0.978 & 0.978 & 0.968 & 0.952 & 0.971 & 0.970 \\
Herbs & 0.983 & 0.982 & 0.979 & 0.982 & 0.984 & 0.990 & 0.978 \\
\hline
\end{tabular}


Table 3. Species composition similarity index based on Sorensen's similarity index [2C/(A+B)] $x$ 100] of the overall species below the vertical line and tree species above the vertical line within the six villages in Mizoram.

\begin{tabular}{lllllll}
\hline Villages & Sairang & Selesih & Thingsulthliah & Serchhip & Keitum & \\
Chhiahtlang & 1 & 2 & 3 & 4 & 5 & 6 \\
\hline 1.Sairang & - & 91.18 & 88.67 & 75.36 & 71.84 & 78.47 \\
2. Selesih & 86.67 & - & 86.63 & 68.06 & 73.68 & 75.65 \\
3.Thingsulthliah & 69.55 & 74.38 & - & 76.84 & 70.90 & 73.96 \\
4. Serchhip & 64.56 & 62.74 & 68.83 & - & 83.94 & 85.71 \\
5. Keitum & 67.37 & 65.29 & 65.66 & 76.76 & - & 82.05 \\
6. Chhiahtlang & 70.63 & 69.41 & 66.92 & 78.10 & 51.17 & -
\end{tabular}

Where, $\mathrm{A}$ and $\mathrm{B}$ are the total species in stand $\mathrm{A}$ and $\mathrm{B}$ respectively, while $\mathrm{C}$ is the number of species common to both stands. 
Table 4. Correlation matrix between the garden size, total number of specie and different use categories of species.

\begin{tabular}{|c|c|c|c|c|c|c|c|c|c|c|c|c|c|}
\hline & $\begin{array}{l}\text { Garden } \\
\text { size }\end{array}$ & $\begin{array}{l}\text { Total \# of } \\
\text { species }\end{array}$ & Fencing & Food & Fruits & $\begin{array}{l}\text { Fuel } \\
\text { wood }\end{array}$ & Medicinal & $\begin{array}{l}\text { Other } \\
\text { uses }\end{array}$ & Ornamental & Roofing & Spice & Timber & Trade \\
\hline Garden size & - & & & & & & & & & & & & \\
\hline \multicolumn{14}{|c|}{ Total \# of species $0.820 * * *$} \\
\hline Fencing & $0.499 * * *$ & $0.524 * * *$ & & & & & & & & & & & \\
\hline Food & $0.650 * * *$ & $0.846 * * *$ & $0.434 * *$ & - & & & & & & & & & \\
\hline Fruits & $0.609 * * *$ & $0.646 * * *$ & $0.432 * *$ & $0.471 * * *$ & - & & & & & & & & \\
\hline Fuel-wood & $0.441 * *$ & $0.531 * * *$ & $0.104^{\mathrm{ns}}$ & $0.355^{*}$ & $0.274 *$ & - & & & & & & & \\
\hline Medicinal & $0.678 * * *$ & $0.879 * * *$ & $0.452 * * *$ & $0.711 * * *$ & $0.498 * * *$ & $0.393 * *$ & - & & & & & & \\
\hline Other uses & $0.731 * *$ & $0.858 * * *$ & $0.366^{*}$ & $0.626 * * *$ & $0.471 * * *$ & $0.509 * * *$ & $0.642 * * *$ & - & & & & & \\
\hline Ornamental & $0.419 * *$ & $0.540 * * *$ & $0.227 *$ & $0.361 * *$ & $0.133^{\mathrm{ns}}$ & $0.348 * *$ & $0.519 * * *$ & $0.440 * *$ & - & & & & \\
\hline Roofing & $0.175^{\mathrm{ns}}$ & $0.310^{*}$ & $0.009^{\mathrm{ns}}$ & $0.296 *$ & $0.048^{\mathrm{ns}}$ & $0.153^{\mathrm{ns}}$ & $0.305^{* *}$ & $0.282 *$ & $0.208^{\mathrm{ns}}$ & - & & & \\
\hline Spice & $0.321 *$ & $0.407 * *$ & $0.149^{\mathrm{ns}}$ & $0.265^{*}$ & $0.202 *$ & $0.325^{*}$ & $0.272 *$ & $0.407 * *$ & $0.174^{\mathrm{ns}}$ & $0.071^{\mathrm{ns}}$ & - & & \\
\hline Timber & $0.678 * * *$ & $0.748 * * *$ & $0.475 * * *$ & $0.614 * * *$ & $0.523 * * *$ & $0.430 * *$ & $0.524 * * *$ & $0.652 * * *$ & $* 0.290 *$ & $0.187^{\mathrm{ns}}$ & $0.217^{\mathrm{ns}}$ & - & \\
\hline Trade & $0.366^{*}$ & $0.422 * *$ & $0.257^{*}$ & $0.212 *$ & $0.291 *$ & $0.186^{\mathrm{ns}}$ & $0.401 * *$ & $0.269 *$ & $0.416^{* *}$ & $0.073^{\mathrm{ns}}$ & $0.233 *$ & $0.267 *$ & - \\
\hline
\end{tabular}

$* * * \mathrm{P}<0.001, * * \mathrm{P}<0.01, * \mathrm{P}<0.05, \mathrm{~ns}=$ not significant $(\mathrm{N}=90)$. 


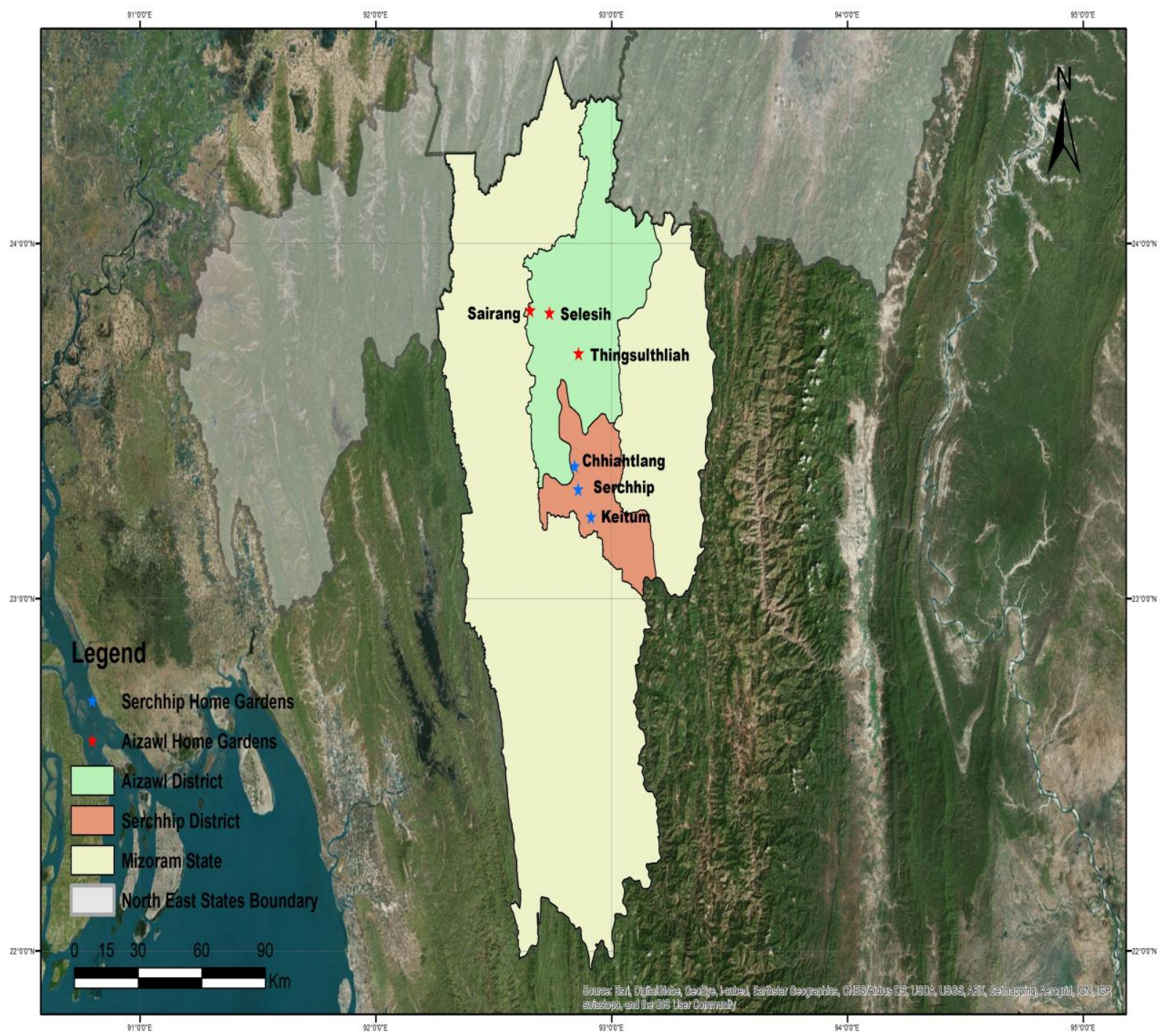

Figure 1. Map showing the villages where home gardens are located in Aizawl and Serchhip district, Mizoram, NEI. 


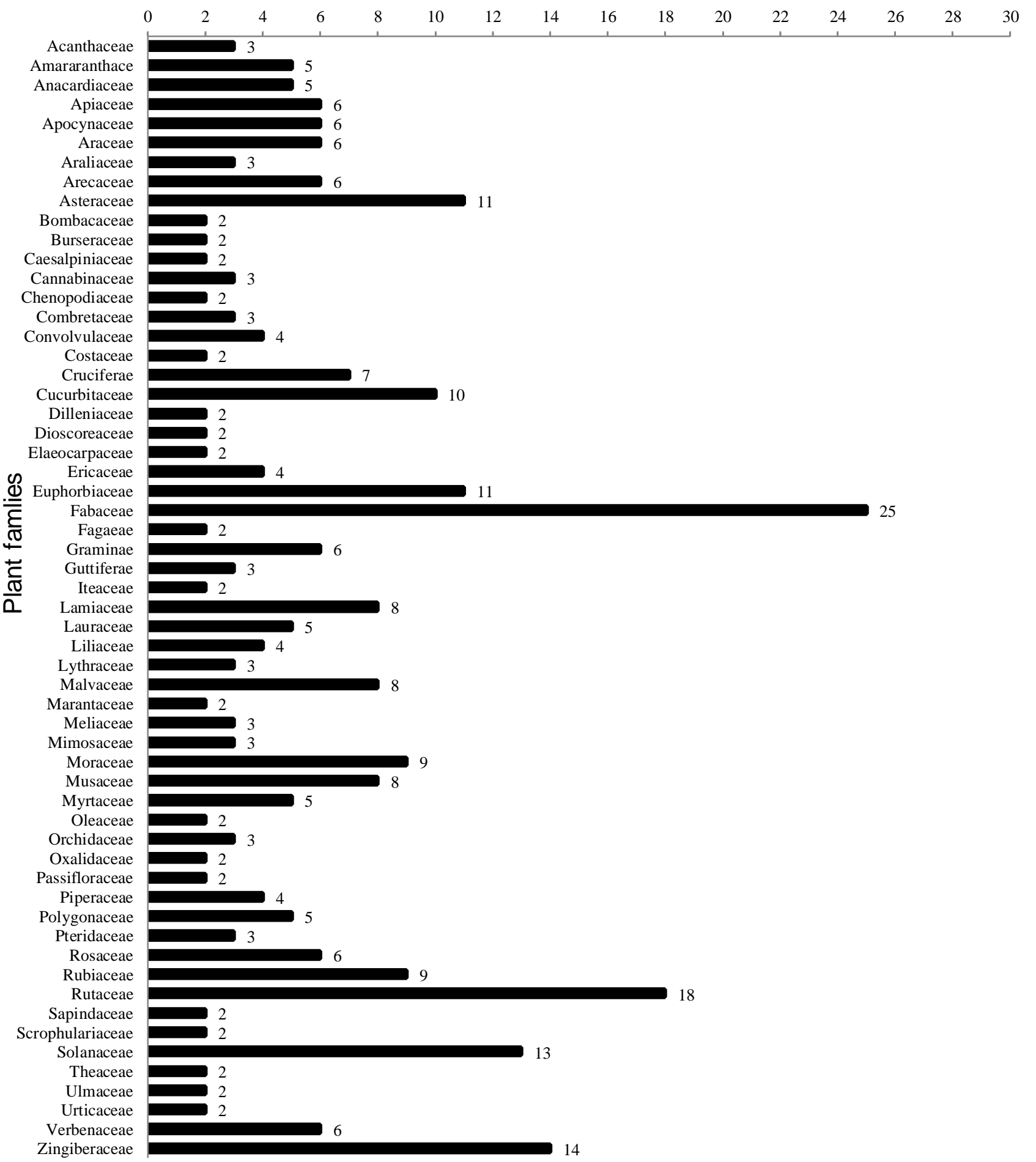

Number of species

Figure 2. Species-rich plant families $(\geq 2)$ in the home gardens in Mizoram. 


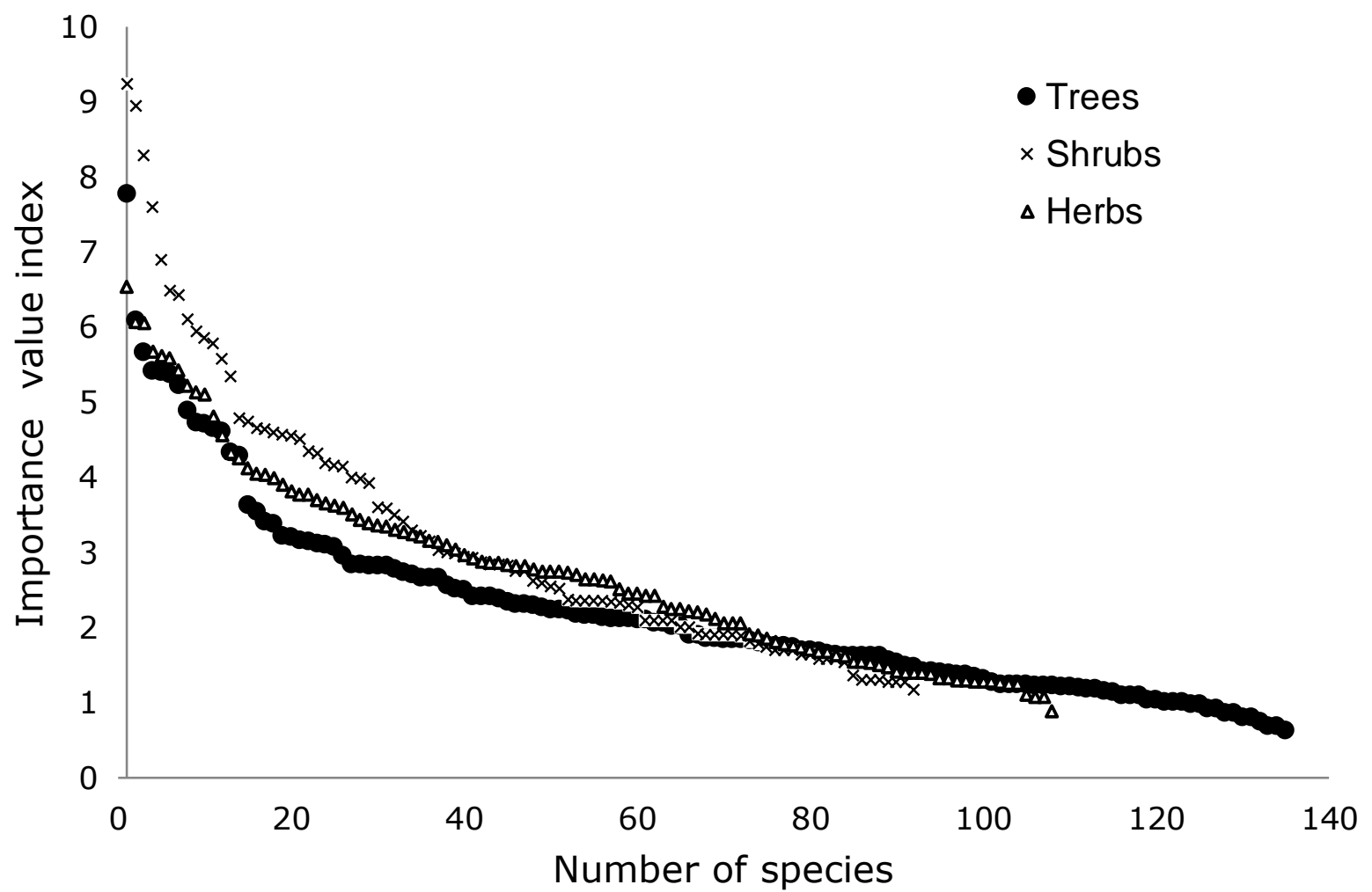

Figure 3. Importance value distribution curve of tree, shrubs and herbs species in the six home-gardens in Mizoram. 


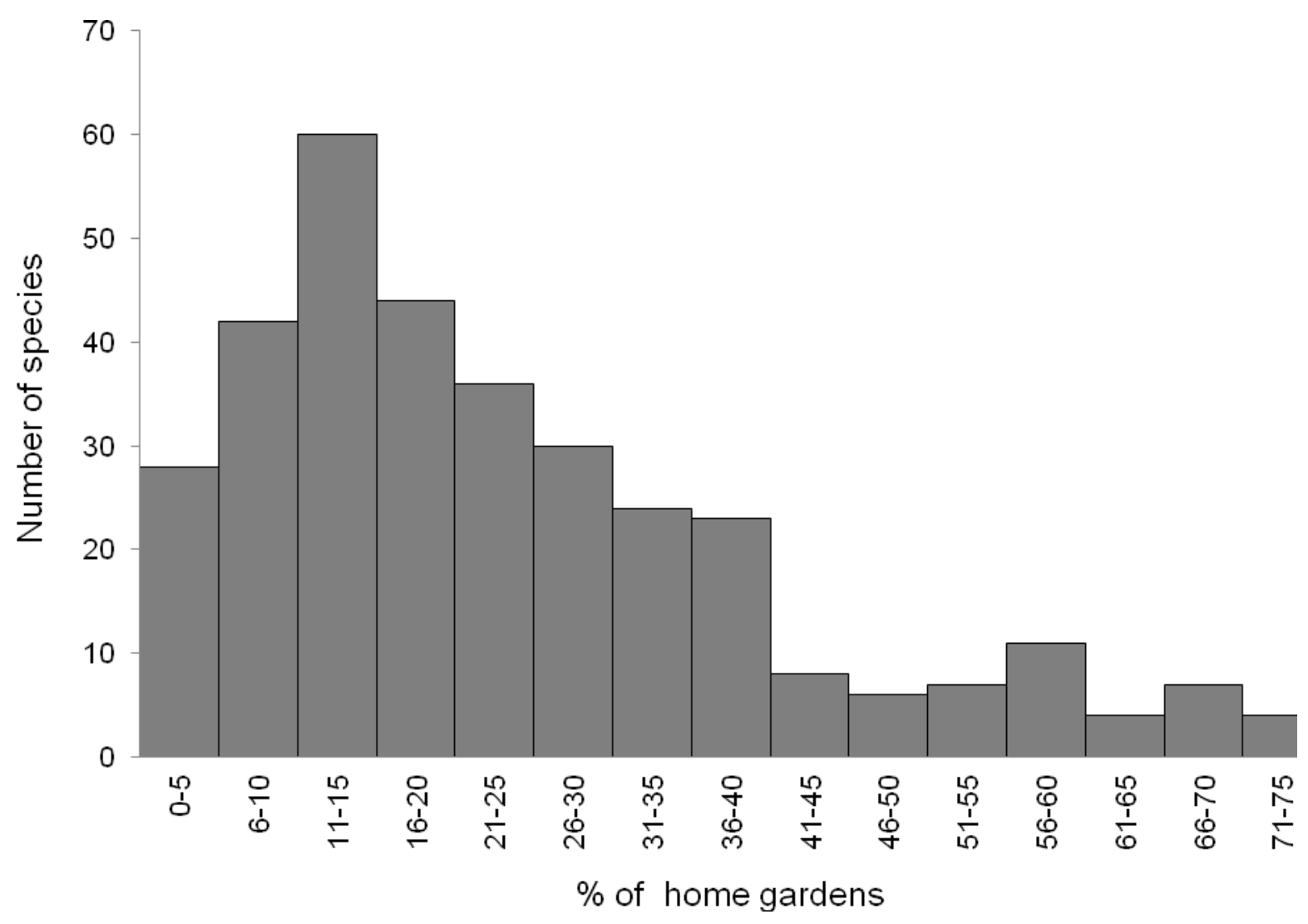

Figure 4. Frequency distribution of species richness. 